Renata

Mihalič,

Fakulteta za

družbene vede

Univerze $v$

Ljubljani

\title{
MENEDŽER ZNANJA - POKLIC PRIHODNOSTI
}

\section{POVZETEK}

Prispevek obravnava problematiko razvoja menedžmenta znanja, s posebnim poudarkom na preučevanju nastajajočega profila menedžerja znanja. Vloga menedžerja znanja je na eni strani osvetljena kot veščina sodobne prakse, ki bi jo moral v organizaciji obvladovati vsak neposredni vodja in zlasti vsak strokovnjak, ki se ukvarja s področjem izobraževanja, izpopolnjevanja in usposabljanja sodelavcev. Na drugi strani pa je menedžer znanja predstavljen kot popolnoma nov profil strokovnjaka s specifičnimi znanji in spretnostmi ter kot poklic, ki ga že lahko zasledimo predvsem $v$ tujil organizacijah zodlično poslovno prakso.

Ključne besede: znanje, menedžment znanja, izobraževalni menedžment, vodenje, menedžer znanja, kompetence, poslovna odličnost

$\mathrm{N}_{\mathrm{a}}$ raziskave na področju razvoja menedžmenta človeškega kapitala so potrdile, da sta uspešnost in učinkovitost vsake organizacije bolj kot kdajkoli prej odvisni od uspešnosti in učinkovitosti menedžmenta znanja, izobraževalnega menedžmenta, menedžmentà človeških virov in menedžmenta sprememb (Lawler-Mohrman, 2003). Ne le v znanstvenih raziskavah in teoriji, temveč tudi v praksi najuspešnejših se vztrajno potrjuje, da odlične organizacije odlično upravljajo $\mathrm{z}$ zaposlenimi in njihovimi znanji. Ključ do uspeha, na katerega prisegajo najboljši, je permanentno pridobivanje novih znanj in nadgrajevanje obstoječih. Filozofija stalnega nadgrajevanja posameznika ali odhod iz organizacije (angl. "up or out") tako danes

Zaposlite znanja lačne ljudi, ponudite jim izziv in jih podprite. Sodelavci vam bodo vračali tako, da bodo delali resnično s srcem, vi pa boste s tem pridobili zmagovalni tim. (Mike Pegg. Pozitivno vodenje, 1996) nima več negativnega prizvoka, ampak postaja popolnoma samoumevna strategija in edini pravi način vsakodnevnega delovanja najbolj iskanih in najbolj zaželenih organizacij in posameznikov.

Navedeni razvojni trendi so nedvomno odsev zlate dobe znanja kot ključnega kapitala, v katero smo tudi pri nas dokoněno vstopili z razcvetom področij menedžmenta znanja in izobraževalnega menedžmenta. V Sloveniji smo še pred tremi leti na tem področju le občudovali tuje primere bogatih praks upravljanja z znanjem in izobraževanjem, danes pa smo s pomočjo benchmarkinga in lastne inovativnosti že uspeli $v$ prakso uspešno prenesti številne sodobne pristope in koncepte politik menedžmenta znanja in izobraževalnega menedžmenta.

$\mathrm{V}$ tem kontekstu je tako $\mathrm{v}$ tujini kot tudi pri nas za razcvet menedžmenta znanja $\mathrm{v}$ praksi zaslužna predvsem menedžerska sfera naprednih organizacij, ki je tudi vir najboljših praks na tem področju. Ravno menedžment 
je vzporedno $\mathrm{z}$ razvojem tega področja vzpodbudil potrebo po strokovnjakih za upravljanje znanja. V praksi se je namreč izkazalo, da je menedžment znanja predvsem veščina, ki jo mora obvladovati vsak vodja, vendar pa je glede na pomembnost področja in njegovo izjemno kompleksnost ter zahtevnost za to potreben izključno specialist. Tovrstnih spodbud s strani menedžmenta je sicer vedno več, vendar so ti še vedno $v$ manjšini in zato tudi menedžer znanja kot delovno mesto in kot profil strokovnjaka še vedno ni prepoznaven s strani trga delovne sile (Buchan, 2003). Slednje sicer ni presenetljivo glede na dejstvo, da velika večina menedžerjev še vedno ne ve, kakšen poklic to sploh je. Po drugi strani pa se nekateri zelo dobro zavedajo pomembnosti tovrstnih strokovnjakov in zelo natančno razločujejo, za kakšen profil gre, saj poznamo primer inovativnega podjetja v Avstraliji, ki v svoji sistematizaciji delovnih mest ločuje že med glavnim menedžerjem znanja, pomočnikom glavnega menedžerja znanja, strokovnim sodelavcem za menedžment znanja in celo koordinatorjem za menedžment znanja.

$\mathrm{Na}$ osnovi navedenega smo torej priča nekoliko kaotičnemu stanju, ko nujno potrebujemo menedžerje znanja kot strokovnjake, vendar zaradi njihovega pomanjkanja in prehodnega obdobja zahtevamo od vodij vlogo in obvladovanje veščin menedžerjev znanja. Kje se nahaja meja med vodjo $v$ funkciji upravljanja znanj in kdaj potrebujemo profesionalen pristop izključno menedžerja znanja, kdo bo izobraževal menedžerje znanja, kakšna je prihodnost tega nastajajočega poklica in kakšen je sploh profil menedžerja znanja, so sicer zahtevna vprašanja, vendar bomo v nadaljevanju poskušali poiskati nekatere realne odgovore. Najprej pa je za razumevanje vloge menedžerja znanja potrebno osvetliti področje menedžmenta znanja in izobraževalnega menedžmenta.

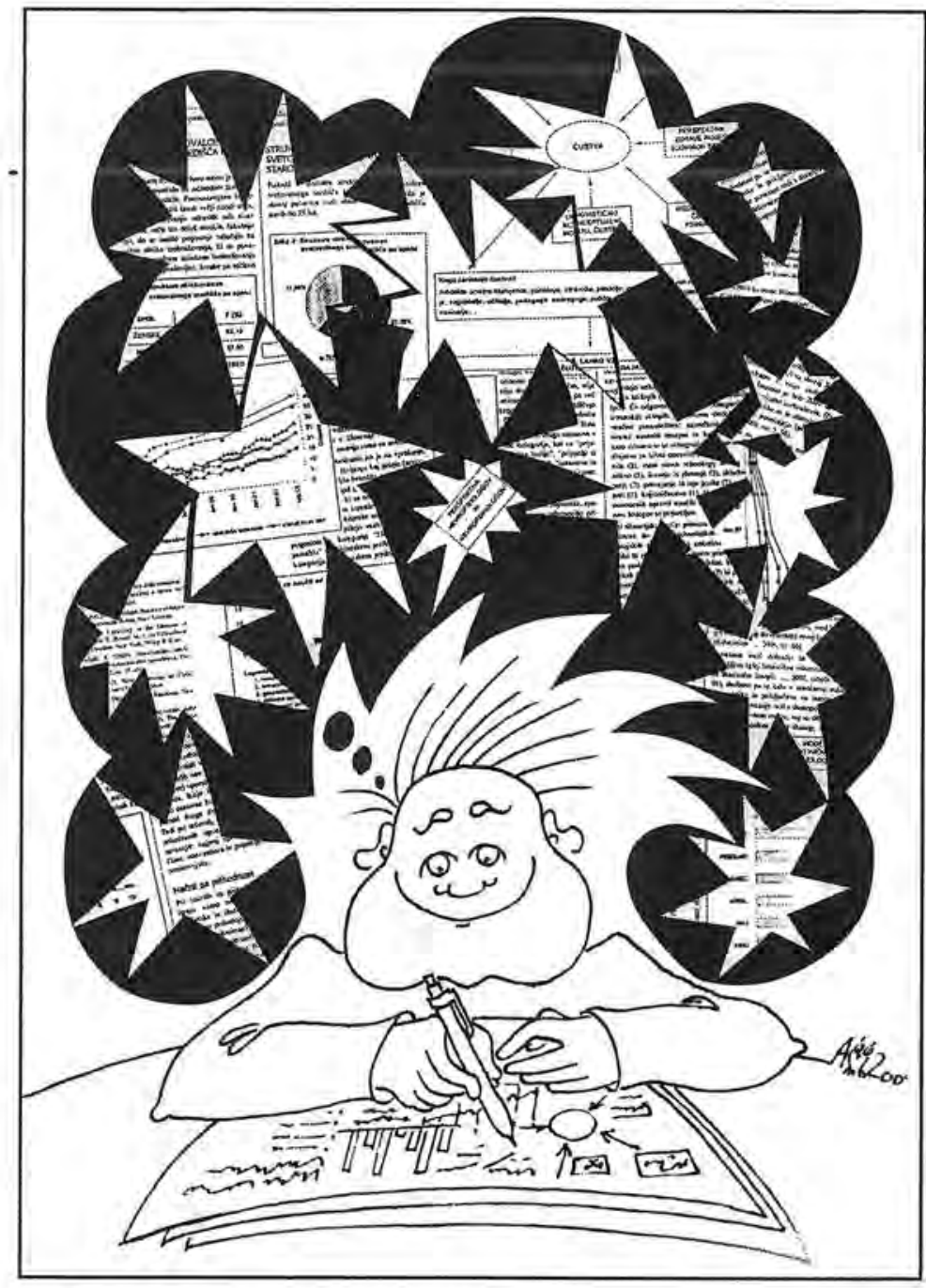

\section{MENEDŽMENT ZNANJA IN IZOBRAŽEVALNI MENEDŽMENT}

Največji izzivi sodobnih organizacij se danes nahajajo $\mathrm{v}$ umetnosti integriranja znanja in procesov, kar zahteva popolnoma nove načine organiziranja (Miklavčič-Mihalič, 2004), Posledično smo danes priča množičnemu redefiniranju vloge tako organizacijskih enot kot tudi strokovnjakov, ki imajo izobraževalno funkcijo $v$ organizacijah. To potrebo po zadnjih radikalnih spremembah je povzročil razcvet menedžmenta znanja in izobraževalnega menedžmenta $v$ okviru razvoja inte- 
lektualnega kapitala, katerega intenzivni razvoj traja v ZDA zadnjih deset let, pri nas pa zaznamuje obdobje zadnjih treh let.

\section{Menedžment znanja - veščina vsakega vodje.}

Menedžment znanja je aktivnost, ki podpira paradigmo upravljanja intelektualnega kapitala (Davis, 2000). Menedžment znanja $v$ bistvu predstavlja nadgradnjo izobraževalnega menedžmenta, $v$ praksi pa ti dve področji z izvajanjem funkcij tvorita sklenjen in integriran krog. Največje učinke lahko ti dve področji dosegata le $\mathrm{v}$ sožitju in nujni močni podpori menedžmenta človeškega kapitala.

Temeljna naloga izobraževalnega menedžmenta in menedžmenta znanja je vzpostavljanje in razvoj filozofije učečih se sistemov (družb, organizacij, skupin, timov in

\section{Gospodarjenje z znanjem je temelj- na funkcija mene- džerja znanja.}

posameznikov), kjer so vsi pripadniki vključeni $\mathrm{v}$ sistematičen proces učenja in gospodarjenja s pridobljenimi znanji. $\mathrm{Z}$ izvajanjem politike učečih se sistemov lahko izobraževalni menedžment zagotavlja procese stalnega učenja (angl. lifelong learning concept). Koncepti vseživljenjskega učenja temeljijo na novi kulturi učenja, ki se preko stalnega in sistematičnega izobraževanja, izpopolnjevanja in usposabljanja izvaja vse življenje. Po definiciji Memoranduma o vseživljenjskem učenju (Memorandum of Lifelong Learning, 2000), ki ga je pripravila Komisija evropske

Menedžment znanja in izobraževalni menedžment predstavljata ključni del razvoja človeškega kapitala vsake sodobne organizacije, ne glede na področje delovanja. Izobraževalni menedžment izvaja načrtovanje, organiziranje, vodenje in nadzorovanje procesov izobraževanja, izpopolnjevanja in usposabljanja, Menedžment znanja pa vrši naloge oblikovanja, načrtovanja, uporabe in prenosa znanj ter splošnega gospodarjenja $\mathrm{z}$ znanjem kot temeljnim izdelkom izobraževalnih dejavnosti. skupnosti, je vseživljenjsko učenje opredeljeno kot vseobsegajoča, trajna učna aktivnost za izboljševanje znanja, spretnosti in veščin, $\mathrm{ki}$ jih posameznik potrebuje za aktivno državljanstvo, socialno povezanost in zaposljivost. Gre torej za zahtevno aktivnost izobraževalnega menedžmenta, katere končni izdelek je znanje. Slednje pa takoj postane predmet preučevanja in zadolžitev menedžmenta znanja.

Medtem ko je temeljna filozofija izobraževalnega menedžmenta načelo stalnega učenja, pa je temeljna filozofija menedžmenta znanja načelo gospodarjenja s pridobljenim znanjem. V tem kontekstu so temeljne naloge menedžmenta znanja naslednje:

- analiziranje in načrtovanje potrebnih znanj,

- razvoj korporativnega znanja in znanja posameznika,

- zagotovitev optimalne uporabe pridobljenih znanj v praksi,

- stalno nadgrajevanje obstoječih znanj z novimi,

- razvoj načel splošnega gospodarjenja z znanjem,

- vzpostavitev sistemov pretoka znanj znotraj sistema,

- zagotovitev sistemov dotoka novih in potrebnih znanj $v$ sistem,

- preprečitev pretiranega odtoka znanj iz sistema,

- evalviranje sistemov pridobivanja znanj in upravljanja z znanjem,

- usklajevanje dejanskih, želenih in potrebnih znanj posameznikov,

- integracija s sistemi nagrajevanja in napredovanja v organizaciji,

- razvoj zavesti o znanju kot vrednoti,

- sistematično odkrivanje in uporaba tihega znanja,

- vzporedno izvajanje politike trženja znanja, 
- uvajanje modelov odličnosti na tem področju (angl. total knowledge management - TKM),

- izvajanje procesov standardizacije znanj in

- sodelovanje $\mathrm{v}$ postopkih varovanja intelektualne lastnine.

Navedene osnovne naloge menedžmenta znanja in izobraževalnega menedžmenta kažejo na kompleksnost in interdisciplinarnost področja, predvsem pa izražajo potrebo po strukturiranem in strokovnem ter razvojnem pristopu specialistov za to področje.

\section{VEŠČINA MENEDŽMENTA ZNANJA V VODENJU}

Neposredni vodja danes pridobiva vedno večjo odgovornost pri zagotavljanju ustrezne ravni znanj in veščin, ki jih sodelavec potrebuje za uspešno in učinkovito delo. S tem neposredni vodja vzporedno pridobiva vedno večjo moč upravljanja $\mathrm{z}$ izobraževanjem, izpopolnjevanjem in usposabljanjem sodelavca ter tudi vedno večjo moč upravljanja z njegovim znanjem.

Vsekakor so navedene naloge na področju menedžmenta znanja za vsakega vodja prevelik zalogaj, še zlasti v velikih sistemih in v primeru petdesetih ali več podrejenih sodelavcih. Ne glede na to, da bi za te naloge potrebovali menedžerja znanja in da ga danes žal navadno $v$ organizaciji še nimamo, pa mora vsak uspešen neposredni vodja ob pomoči in sodelovanju kadrovikov kljub temu prevzeti določene obveznosti in naloge $s$ področja menedžmenta znanja do svojega sodelavca.

Prva naloga vsakega neposrednega vodje je prenos znanj. Strateško pomembno je namreč, da vodja sistematično prenaša svoja znanja na sodelavce in hkrati zagotovi, da tudi sodelavci prenašajo svoja znanja nanj in
Vsak dober vodja bi moral, ne glede na raven vodenja, sistematično načrtovati, organizirati, voditi in nadzorovati procese pridobivanja znanj sodelavea, obenem bi moral zagotoviti optimalno uporabo pridobljenih znanj $\mathrm{v}$ praksi in nadaljnji prenos teh znanj na druge zaposlene, sodelavca bi moral motivirati za stalno pridobivanje novih znanj, usklajevati njegova dejanska znanja $\mathrm{z}$ zahtevanimi znanji, skrbeti za realizacijo njegovega letnega načrta izobraževanja in tako naprej. Optimistično, nerealno, iluzorno ... ali pa morda delo za menedžerja znanja?

na druge sodelavce. Izjemno neodgovorno je, če neposredni vodja ne zagotavlja kontinuitete in oplemenitenja znanj, saj s tem dolgoročno pretvarja svoje bogato znanje $\mathrm{v}$ mrtvo znanje. Enako neodgovorno pa je tudi, če neposredni vodja ne izkoristi znanj svojih sodelavcev. Pri tem velja zlato pravilo, da nudimo odličnost in pričakujemo odličnost. Popoln izkoristek umskega potenciala je pri tem sicer iluzoren, lahko pa vsak neposredni vodja načrtno odkriva tiha znanja, zagotavlja manjkajoča znanja in nadgrajuje obstoječa glede na trenutne in predvidene potrebe. Vzporedno s tem je zaželeno, da je vodja pozoren na niše v sistemu, kjer bodo

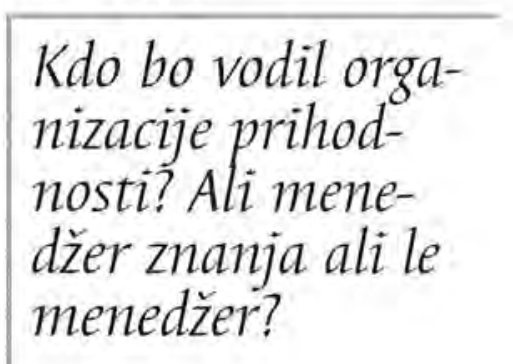
ta znanja glede na spremembe in potrebe lahko še uporabnejša. V tem je tudi bistvo vizije pravih ljudi na pravem delovnem mestu, ob pravem času, s pravimi znanji danes in v prihodnosti.

Neposredni vodja ima največjo priložnost, da razvije svoje sodelavce tako, da bodo $\mathrm{v}$ največji možni meri primerni za opravljanje sedanjih in predvidenih del in nalog na določenem področju. Pri tem nosi tudi večinsko odgovornost za razvoj sodelavcev, ki mora biti seveda popolnoma $\mathrm{v}$ skladu s potrebami organizacije. Od vodij se na eni strani zahteva stalno lastno nadgrajevanje in pridobivanje novih znanj, na drugi strani pa 


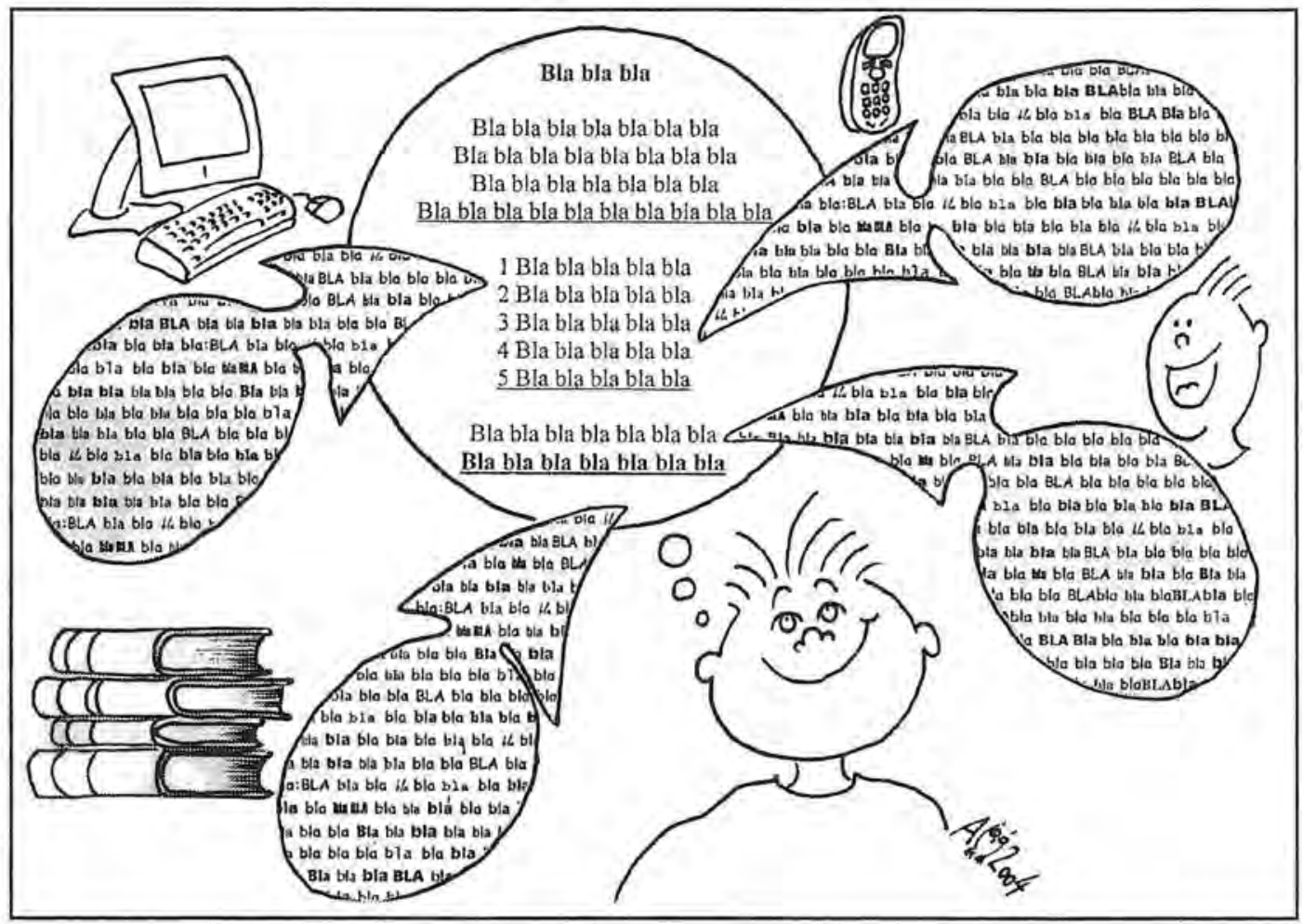

skrb za nadgrajevanje svojih sodelavcev. Vendar se pri tem dober vodja zaveda, da z nadgrajevanjem znanj svojih sodelavcev in njihove posledične večje uspešnosti vzporedno nadgrajuje in povečuje tudi lastno uspešnost in uspešnost organizacije kot celote. Druga ključna skupina, ki potrebuje aktivnejši prenos znanja s strani bolj izkušenega neposrednega vodje, so kandidati za naslednike. Vsak neposredni vodja mora iz lastne odgovornosti in odgovornosti do organizacije poskrbeti za zagotovitev nasledstva. Pri tem bi moral vsak vodja, ne glede na raven vodenja, v svoji karieri sistematično izvajati razvoj naslednikov, in sicer ne le na enem izmed svojih sodelavcev, temveč hkrati vsaj na dveh ali treh perspektivnih kandidatih. Tretja skupina, ki ji moramo posvetiti večjo pozornost pri načrtnem prenosu znanj, pa so novi sodelavci brez predhodnih delovnih izkušenj. V primeru, da tovrstnim kadrom že takoj na začetku delovne poti dovolimo samouspavanje na znanjih, večinoma pridobljenih $v$ okviru formalnega šolanja, se čez leto ali dve ne smemo čuditi, zakaj posameznik še vedno ne izpolnjuje naših pričakovanj

Največjo pozornost upravljanja znanj je potrebno namenjati predvsem vodilnim in vodstvenim kadrom, najbolj talentiranim sodelavcem, mladim sodelavcem brez predhodnih delovnih izkušenj in kandidatom za morebitne naslednike. Navedenim ključnim skupinam je namreč potrebno zagotoviti hitrejše pridobivanje znanj kot ostalim sodelavcem, zahtevajo pa tudi posebno pozornost s strani neposrednega vodje. Vodilni in vodstveni ter izjemno talentirani sodelavci potrebujejo za svoj razvoj hitrejše in kakovostnejše pridobivanje znanj, večjo odgovornost in izzive. Omogočanje intenzivnega učenja je pri tovrstnih kadrih tudi eden izmed najboljših načinov, da jih bomo zadržali v organizaciji. 
Menedžer znanja skrbi za razvoj menedžmenta znanja v okviru razvoja človeškega kapitala, načrtuje, organizira, vodi, nadzoruje in analizira procese pridobivanja znanj in prenašanja teh znanj $v$ prakso, razvija in uvaja nove metode in tehnike $v$ izobraževanje in gospodarjenje $\mathrm{z}$ znanjem, skrbi za stalno izobraževanje vseh sodelavcev, oblikuje razvojno vizijo, politiko ter strateške, taktične in operativne cilje na področju upravljanja znanja in izobraževanja, pripravlja predloge za spremembe v izobraževanju in ravnanju z znanjem, skrbi za razvojno in raziskovalno dejavnost na področju menedžmenta znanja, uvaja nova orodja in modele odličnosti pri upravljanju z znanjem, pripravlja usmeritve za upravljanje znanja sistema, strokovno svetuje ter oblikuje metodologijo in koncepte za uspešno in učinkovito izvajanje procesov izobraževanja in gospodarjenja z znanjem.

pri delu. Slednje mora preprečiti ravno neposredni vodja, še posebej glede na to, da so ti sodelavci najdovzetnejši za pridobivanje znanj in da so, ker nimajo delovnih izkušenj, torej tudi ne slabih, zato idealni za uspešno in učinkovito učenje.

Navedene aktivnosti zahtevajo od neposrednih vodij dobro obvladovanje osnovnih veščin menedžmenta znanja. Za celosten pristop $\mathrm{k}$ upravljanju izobraževanj in znanj oziroma upravljanju vseh kompetenc sodelavcev pa je ta naloga za neposredne vodje prezahtevna in tudi nesmiselna. Vodje se morajo namreč najprej ukvarjati z upravljanjem ljudi, za upravljanje njihovih znanj pa tako vodje kot organizacija nujno potrebujejo pomoč ustreznega usposobljenega strokovnjaka - menedžerja znanja.

\section{STROKOVNI PROFIL IN NALOGE MENEDŽERJA ZNANJA}

Vloga in naloge profesionalnega menedžerja znanja vključujejo vse naloge, vezane na področje upravljanja z izobraževanjem, izpopolnjevanjem in usposabljanjem ter področje upravljanja z znanjem. Menedžer znanja kot specialist je hkrati v vlogi upravljanja izobraževanja iz naslova funkcij izobraževalnega menedžmenta in v vlogi upravljanja znanja iz naslova funkcij menedžmenta znanja.

Ključna naloga menedžerja znanja je usklaje- vanje obstoječih, želenih in zahtevanih znanj glede na organizacijske vloge, ki jih zaposleni zasedajo oziroma se zanje predvideva, da naj bi jih zasedali $v$ prihodnosti. Pri tem menedžer znanja skrbi za korporativne, timske, skupinske in individualne profile znanj v povezavi z delovnimi, vodstvenimi, izobraževalnimi in mobilnostnimi potenciali. Na tej točki je pomembno sodelovanje menedžerja znanja pri pripravi kariernih načrtov posameznikov, izvedbi letnih razgovorov neposrednih vodij s sodelavci, oblikovanju in realizaciji individualnih načrtov izobraževanja posameznika, oblikovanju predlogov nagrajevanja sodelavcev ter pri pripravi načrtov napredovanja in nasledstva.

Navedeni celostni pristopi $\mathrm{k}$ upravljanju znanj in izobraževanj ter sodelovanje pri sistemih, ki vključujejo elemente učenja in znanj, so sicer izjemno zahtevne naloge za menedžerja znanja, vendar pa je kljub temu njegova najzahtevnejša naloga vezana na

Najzahtevnejša vloga menedžerja znanja je graditev izobraževalne kulture. vzpostavljanje primerne izobraževalne kulture in klime v organizaciji. V Sloveniji poznamo že veliko podjetij, ki imajo resnično zelo dobre sisteme pridobivanja znanj in upravljanja $z$ že pridobljenimi znanji sodelavcev, vendar pa $v$ preučevanju številnih domačih praks na tem področju osebno še nisem zasledila podjetja, kjer je učenje dol-
AS BI: 
Zagotovitev pogojev za uspešno in učinkovito delo menedžerja znanja zahteva njegovo tesno sodelovanje $\mathrm{z}$ vodilnimi in vodstvenimi kadri v organizaciji in predvsem z vsemi ključnimi kadri kot poznavalei sistema kot celote. Obenem mora menedžer znanja vodilne in vodstvene kadre strokovno usmerjati pri upravljanju znanja njihovih sodelavcev na taktični ravni ter jim zagotavljati svetovalno, metodološko in konceptualno podporo na tem področju vodenja.

žnost in pravica resnično vsakega zaposlenega (ne glede na delovno mesto, starost, izkušnje ali potencial). Slednje ne kaže na kakršenkoli manko $v$ prizadevanjih, kaže le na izjemno težko nalogo spreminjanja odnosa do znanja, osveščanja o odgovornosti vsakega

Učenje je dolžnost in pravica slehernega zaposlenega. posameznika za lasten razvoj, privzgajanja pomembnosti vlaganja $v$ lastno znanje in posledičnega zvišanja lastne cene na trgu delovne sile ter predvsem spreminjanja stališč in načina razmišljanja. Menedžer znanja mora torej skrbeti tudi za razvoj in vzdrževanje izobraževalne klime $v$ organizaciji, kar pomeni vzpostavitev takega psihološkega ozračja med zaposlenimi, ki bo vzpodbudno vplivalo na stalno izobraževanje ter predvsem na aktivno razširjanje pridobljenega znanja.

\section{Menedžer znanja je strateški par- tner vodilnega menedžmenta.}

Osnovni pokazatelji visoke stopnje razvitosti dimenzije izobraževanja, kot ene izmed ključnih dimenzij organizacijske klime, so predvsem večinsko zavedanje zaposlenih, da je potrebno za ohranjanje lastne konkurenčnosti stalno nadgrajevati pridobljena znanja, večinsko mnenje zaposlenih, da imajo dovolj možnosti za pridobivanje dodatnih znanj, ki jih potrebujejo za uspešno in učinkovito opravljanje del in nalog, večinsko občutenje zaposlenih, da jih neposredni vodja spodbuja $\mathrm{k}$ stalnemu izobraževanju, večinsko medsebojno prenašanje znanja med sodelavci in stalno učenje drug od drugega. V tem kontekstu je menedžer znanja najprej tisti, ki navdušuje sodelavce za stalno pridobivanje novih znanj in preprečuje njihovo samouspavanje na pridobljenem znanju.

Pomembne vzporedne naloge menedžerja znanja so vezane na povečevanje stopnje aktivne udeležbe sodelavcev v procesih pridobivanja in širjenja znanja, pospeševanje inovativnosti in samoiniciativnosti zaposlenih, evalviranje programov pridobivanja znanj, merjenje stopnje aplikacije pridobljenih novih znanj v prakso in merjenje vpliva znanja na učinkovitost in uspešnost pri delu.

Pri tem gre za partnersko sodelovanje, zaželeno pa je delegiranje določenih nalog menedžmenta znanja od sodelavcev na raven neposrednih vodij. Menedžer znanja mora tesno sodelovati tudi s kadroviki, zato je zaželena organizacijska lociranost menedžerja znanja znotraj organizacijske enote za izvajanje funkcije kadrovanja in razvoja zaposlenih. Menedžer znanja mora imeti tudi možnost stalnega vpogleda $v$ organizacijske cilje, razvojne strategije in taktike, poznati mora zgodovino, sedanjost in predvideno prihodnost organizacije, da bi lahko pravočasno zagotovil in razvijal ustrezne sodelavce $z$ ustreznimi znanji za danes in za prihodnje potrebe.

Vse navedene naloge in vloge menedžerja znanja zahtevajo profiliranje strokovnega nosilca razvoja menedžmenta znanja, ki potrebuje široka znanja tudi na področju upravljanja človeških virov, organizacije, komunikologije, vodenja, psihologije, prava in menedžmenta. Posledično je $v$ velikih organizacijah najprimerneje, da se za to področje oblikuje tim menedžerjev znanja, ki ga sestavljajo andragog, kadrovik, psiholog in pravnik.

Potreba po izobraževanju za poklic menedžerja znanja postaja iz dneva $\mathrm{v}$ dan večja in nujno potrebno bo resno razmisliti o 
Glede na trende, ki jih kažejo izkušnje najuspešnejših po svetu, je menedžer znanja izjemno perspektiven poklic bližnje prihodnosti. Menedžerji znanja bodo $\mathrm{v}$ naslednjih letih nedvomno med najbolj iskanimi strokovnjaki za upravljanje najdonosnejših investicij posameznika - investicij $\mathrm{V}$ učenje in upravljanje najpomembnejšega sodobnega kapitala, to je znanja.

pripravi programa, ki bo lahko oblikoval profil menedžerja znanja ter ga opremil z veščinami in znanji s področja upravljanja znanja in izobraževanja, organizacije, medosebnega komuniciranja, timskega dela, vodenja, koordiniranja, delovnega prava, organizacijske psihologije, projektnega dela, upravljanja s človeškimi viri ter razvojnega in raziskovalnega dela. Najbližje temu programu je program andragogike, ki bi mu kazalo dodati še nekatera nova programska področja in razvijati dodatne kompetence,

\section{ZAKLJUČEK}

Menedžment znanja in izobraževalni menedžment odpravljata tradicionalno vlogo izobraževanja in vzpostavljata sodobno vlogo upravljanja $\mathrm{z}$ izobraževanjem in znanji ter krepita strokovno, razvojno, raziskovalno in znanstveno vlogo menedžmenta znanja $\mathrm{v}$ organizacijah tako $v$ svetu kot tudi pri nas. Uspešno in učinkovito upravljanje z znanji sodelavcev in celostnim korporativnim znanjem pa zahteva vzpostavitev funkcije menedžmenta znanja kot ključnega akterja v strategiji razvoja vsake organizacije ter sistemsko, procesno in organizacijsko približanje te funkcije samemu vrhu organizacije. Menedžment znanja mora postati osnovna pogonska sila organizacijske učinkovitosti, rasti in stalnega napredka.

Menedžer znanja kot strokovni nosilec in generator sprememb na področju ravnanja $\mathrm{z}$ znanjem je nastajajoči profil, brez katerega si kmalu ne bomo več mogli predstavljati uspešne organizacije ali pa si bomo še naprej lahko privoščili primere sodelavcev $\mathrm{z}$ neustreznimi znanji na neustreznih deloynih mestih.

Vzporedno z uvajanjem menedžmenta kompetenc se razširja tudi funkcija menedžerja znanja, saj ni dovolj le upravljanje znanj sodelavcev, temveč je potrebno upravljati vse kompetence (znanj, izkušenj, osebnostnih lastnosti, sposobnosti, prepričanj, zanosa, vrednot, motiviranosti, odzivnih zmožnosti, ustvarjalnosti, sposobnosti upravljanja sprememb, odgovornosti in sa-

Menedžer znanja
je vselej tudi gene-
rator sprememb.
mopodobe). $\mathrm{S}$ tem bodo postajale naloge menedžerjev znanja še veliko kompleksnejše, z razvojem profila menedžerja znanja pa bomo v bližnji prihodnosti morda govorili le še o menedžerju kompetenc kot novem poklicu.

\section{LITERATURA}

Buchan, C. David (2003). Is Knowledge Manager a Recognised Occupation, Thought Horizon, http://www.thoughthorizon.com/archives/000325.php.

Davis, M. (2000). The Value of Knowledge

Management, Intellectual Capital Management,

Knowledge Point Pty Ltd.,

http://www.knowledgepoint.com.au.

Lawler, E., Mohrman, E., Susan, A. (2003), Creating a Strategic Human Resources Organization, An Assessment of Trends and New Directions, Stanford, California.

Miklavčič, M., Mihalič, R. (2004). Sodobni trendi na področju upravljanja človeških virov in človeškega kapitala. Kadrovske informacije. Ljubljana: Vlada Republike Slovenije.

Memorandum o vseživljenjskem učenju, Komisija evropske skupnosti, Bruselj, 2000. 